\title{
Temporal Analysis of Agricultural Production and its Performance in Uttar Pradesh, India
}

\author{
Rooba Hasan ${ }^{1} *$ and Diwan Nayeer $\operatorname{Khan}^{2}$ \\ ${ }^{1}$ Department of Agricultural Economics, Institute of Agricultural Sciences, \\ BHU, Varanasi-221005, India \\ ${ }^{2}$ Manager, SBI Commercial Branch, Near GPO Square, Indore, India \\ *Corresponding author
}

A B S T R A C T

\section{Keywords}

Cropping pattern, production, Agriculture, Growth rate, Uttar Pradesh

Article Info

Accepted:

25 May 2018

Available Online:

10 June 2018
Agriculture is the major livelihood activity of majority of rural population in Uttar Pradesh. Sustained growth in agricultural production and productivity is essential for over all sustainability of the state economy. It is, therefore necessary to analyze the agriculture production pattern and performance of agriculture crops in Uttar Pradesh. This paper deals with analysis of cropping pattern, production pattern and growth rate of agricultural crops in Uttar Pradesh. Cropping pattern was found to be biased towards water intensive crops like rice, wheat and sugarcane. Cereals are found as dominant crop of the state. Maximum area was used for cultivation of cereals followed by pulses. But productivity of sugarcane and potato was highest. Increasing shift towards cash crops like sugarcane and potato was observed which is due to better production performance and yield as compared to staple crops such as cereals and pulses.

\section{Introduction}

Agriculture is the most important sector of Indian Economy and continues to be the single most important livelihood of the masses in India. During 2016-17, there was a record for the production of food grains at 275 million tones, of which 138 million tonnes was during Kharif season and 137 million tonnes during the Rabi season. Of the total foodgrains production, the production of cereals was 252 million tonnes and pulses 23 million tonnes. As per the $3^{\text {rd }}$ advance estimates for 2017-18, total food grains production was estimated
279.5 million tonnes of which 138.73 illion tonnes during Kharif and 140.78 million tones during Rabi seasons (Directorate of Economics \& Statistics, DAC\&FW).

Among all the states of India Uttar Pradesh bears a major responsibility in maintaining the food security as it is the fourth largest state in terms of geographical area (294 thousand $\mathrm{km}^{2}$ ) and ranks first in terms of total population (16.61 million). It has the highest cropped area of 25,785 thousand hectares as well as highest number of over 21 million farm holdings as well. It is also the major contributor to the 
country's food basket. It produces more than 41.1 million tonnes of food grains which is about 20 per cent of total food grains of the country. The state predominately rural and agrarian, about 82 per cent population of the State live in rural areas with 73 per cent of working force engaged in agriculture. It produces not only sufficient food grains, sugarcane and oilseeds for the sustenance of its population but also fulfills the food grains requirement of other states and generates a surplus for export as well. Thus, the total agricultural output of the state has a significant bearing on the nation's food security.

According to Ahluwalia, 1978; Saleth et al., 2003; Hussain and Hanjra(2003-

04) The incidence of rural poverty has also reduced considerably from 56.44 per cent during 1972-73 to 28.33 per cent in 2004-05 mainly because of the improved production of agricultural commodities. However, it has been observed that the share of primary sector in GSDP is witnessing a declining trend. TheThe pace of commercialization in agriculture is found to be slow in state (Fahimuddin 2010). Agricultural development programmes have been taken up in the country and also in the State for enhancing the agricultural production for bringing about uniform regional development and state government is promoting diversification in farm sector.

Although, during the last four decades, agriculture sector in the state has witnessed a convincing growth. There exists wide variation in agricultural performance due to structural deficiencies, differential endowment of natural resources and varying level of technological exposure. Not many studies have been conducted to track the variations and underlying changes in production performance of agriculture sector in Uttar Pradesh. Therefore, present paper examines temporal variations in agricultural production and production performance of agricultural commodities in Uttar Pradesh

\section{Materials and Methods}

The study is primarily based on the secondary data collected from various published sources like Sankhiyiki Patrika of Uttar Pradesh, Uttar Pradesh Bulletin of agriculture Statistics, Government of India etc. The cropping pattern and production pattern of agricultural commodities was investigated using tabular analysis and the compound growth rates (CGR) of area, production and yield were estimated as follows

$$
\begin{aligned}
& \mathrm{Y}_{\mathrm{t}}=\mathrm{AB}^{\mathrm{t}} \\
& \text { where } \\
& \mathrm{Y}_{\mathrm{t}}=\text { area/production/yield of major crops in } \mathrm{t}^{\text {th }} \\
& \text { period, } \\
& \mathrm{T}=\text { time variable }(1,2,3 \ldots \ldots, \mathrm{n}), \\
& \mathrm{A}=\text { constant, } \\
& \mathrm{B}=(1+\mathrm{r}) \\
& \mathrm{R}=\text { compound growth rate. }
\end{aligned}
$$

After log transformation and estimation of the above function as $\ln Y_{t}=\ln A+t \ln B$, compound growth rate was estimated as:

$$
\mathrm{r}=\{\operatorname{antilog}(\ln \mathrm{B})-1\}^{*} 100
$$

To understand the extent of instability in the yield of agricultural commodities, the coefficient of variation $(\mathrm{CV})$ was estimated as follows:

$$
C V=\frac{\sigma}{\bar{X}} x * 100
$$

Where,

$\begin{array}{lll}\sigma_{\mathrm{x}} & = & \text { standard deviation of } \mathrm{X} \\ X & = & \text { mean of } \mathrm{X} . \\ \mathrm{X} & = & \text { area/production/yield }\end{array}$




\section{Results and Discussion}

\section{Region-wise cropping pattern in Uttar Pradesh}

Uttar Pradesh agriculture is highly diversified. It produces numerous crops due to its comparative advantage of wide range of agroclimatic variability. It is

one of the major foodgrain producing states in the country.

Cropping pattern in Uttar Pradesh was examined at four points of time by looking at the share of individual crop's area in gross cropped area (GCA).

It was found to be biased towards waterintensive crops like rice, wheat and sugarcane with share of 24 per cent, 39 per cent and 9 per cent in GCA in TE 2009. Between TE 1995 and TE 2009, due to development of reliable sources of irrigation, the share of water-intensive crops in GCA had increased, while the share of rainfed crops had declined (Table1).

\section{Production pattern of agricultural crops in Uttar Pradesh}

There are different types of agriculture crops in UttarPradesh and India. The major crops have been taken for analysis are cereals, pulses, oilseeds, sugarcane and potato. Temporal changes in the pattern and performance of crop production are presented in Tables 2 and 3. In gross cropped area a small decline was observed in Uttar Pradesh, it decreased from about 233 lakh hectare in TE 1995 to about 231 lakh hectare in TE 2009. Cereals accounted for about three forth of gross cropped area. Total area under cereals was about 168 lakh hectare in TE 1995 constituting about 72 per cent of the gross cropped area. Between TE 1995 and TE 2009 total area under cereals increased to around 171.12 lakh hectare growing at the rate of 0.12 per cent per annum.

Further, the share of cereals in gross cropped area during the same period increased to about 74 per cent from around 72 per cent indicating marginal substitution towards cereals from non-cereal crops. Due to the use of improved varieties, this period witnessed an increase in the yield of cereals from 19.45 quintals/ hectare in TE 1995 to about 21.88 quintals/hectare in TE 2009 with a growth rate of 0.96 per cent per annum. Consequently, cereals production increased from 344 lakh tones in TE 1991 to 401 lakh tones at an annual compound growth rate of 1.15 per cent. Thus, the period witnessed a considerable increase in the production of cereals.

On the other hand, total area under pulses was about 26 lakh hectare in TE 1995 which reduced to about 22 lakh hectare in TE 2009, at the rate of-0.34 per cent (Table 5.1.5). Pulses also witnessed a substantial deceleration in yield growth between TE 1991 to 2009 of -3.98 per cent. Consequently, pulses production had also shown a decreasing trend, it decreased from 48.92 lakh tones in TE 1995 to 26.85 lakh tones in TE 2009 with the growth rate of -3.84 per cent. Pulse production was minimum in TE 2005 (22.34 lakh tonnes).

Area under oilseeds was 8.61 lakh hectares in TE 1995 constituting about 3 per cent share in gross cropped area which increased to 9.55 lakh ha (about 4 per cent) in TE 2009 with the growth rate of 0.19 per cent. This reflected a marginal increase in importance of oilseeds in the cropping pattern as compared to cereals between 1995 and 2009 with a growth rate of 0.19 per cent. But the growth in production and productivity of oilseeds could not keep pace with growth in area. 
Table.1 Cropping pattern in Uttar Pradesh (share of crop's area in gross sown area) (in per cent)

\begin{tabular}{|l|l|l|l|l|}
\hline \multirow{2}{*}{ Crops } & \multicolumn{4}{|c|}{ Uttar } \\
\hline Rice & $\mathbf{1 9 9 5}$ & $\mathbf{2 0 0 0}$ & $\mathbf{2 0 0 5}$ & $\mathbf{2 0 0 9}$ \\
\hline Wheat & 22.99 & 23.74 & 24.02 & $\mathbf{2 4 . 8 4}$ \\
\hline Barley & 37.49 & 38.90 & 39.83 & $\mathbf{4 0 . 1 3}$ \\
\hline Jowar & 1.52 & 1.30 & 0.97 & $\mathbf{0 . 7 9}$ \\
\hline Bajra & 1.97 & 1.53 & 1.06 & $\mathbf{0 . 8 8}$ \\
\hline Maize & 3.68 & 3.75 & 3.86 & $\mathbf{3 . 9 4}$ \\
\hline Urd & 4.38 & 4.14 & 3.19 & $\mathbf{3 . 1 1}$ \\
\hline Moong & 1.19 & 1.54 & 2.28 & $\mathbf{1 . 9 7}$ \\
\hline Masoor & 0.46 & 0.51 & 0.29 & $\mathbf{0 . 2 9}$ \\
\hline Gram & 2.07 & 2.35 & 2.60 & $\mathbf{2 . 2 8}$ \\
\hline Arhar & 4.44 & 3.64 & 3.24 & $\mathbf{2 . 4 8}$ \\
\hline Mustard & 2.26 & 1.84 & 1.56 & $\mathbf{1 . 4 7}$ \\
\hline Sugarcane & 2.88 & 3.00 & 2.41 & $\mathbf{2 . 3 4}$ \\
\hline Potato & 7.67 & 8.22 & 9.07 & $\mathbf{9 . 4 3}$ \\
\hline Other & 1.73 & 1.82 & 1.88 & $\mathbf{2 . 3 0}$ \\
\hline GCA & 5.27 & 3.71 & 3.73 & $\mathbf{3 . 7 5}$ \\
\hline
\end{tabular}

Figures within parenthesis are gross sown area (lakh hectare)

Table.2 Area, production and yield of crops in Uttar Pradesh

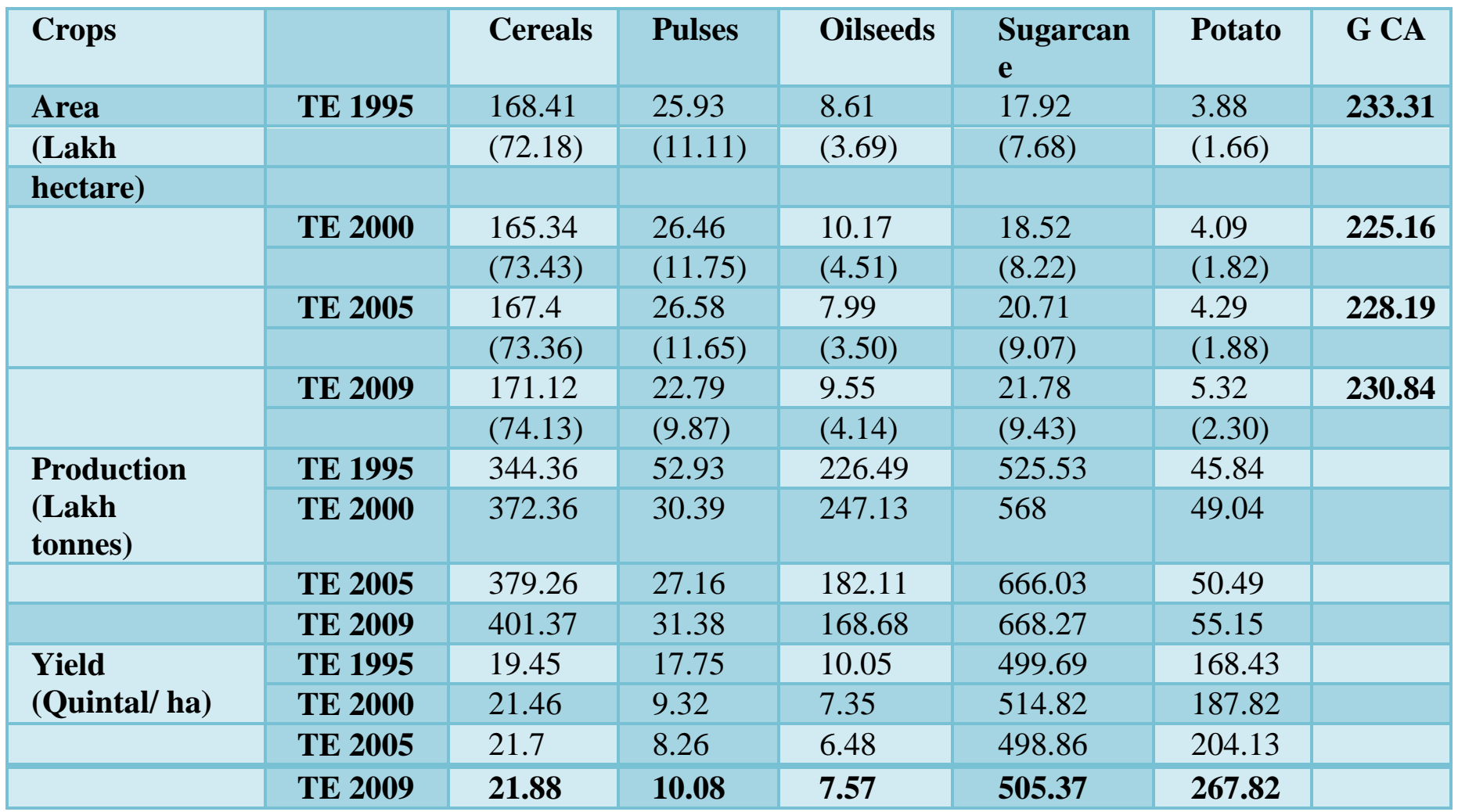

Figures in parenthesis are percentage of gross cropped area (GCA) 
Table.3 Production performance (CGR and CV) of agricultural crops in Uttar Pradesh (1991-2009)

\begin{tabular}{|l|l|l|l|}
\hline Crops & Area & Production & Yield \\
\hline Cereals & 0.12 & 1.15 & $\mathbf{0 . 9 6}$ \\
& $(2.98)$ & $(8.07)$ & $\mathbf{( 7 . 0 2}$ \\
\hline & -0.34 & -3.84 & $\mathbf{- 3 . 9 8}$ \\
\hline Pulses & $(7.92)$ & $(33.89)$ & $\mathbf{( 4 1 . 9 8 )}$ \\
\hline & 0.19 & -2.23 & $\mathbf{- 2 . 2 2}$ \\
Oilseeds & $(14.99)$ & $(23.73)$ & $\mathbf{( 1 7 . 4 3 )}$ \\
\hline & 1.10 & 1.33 & $\mathbf{0 . 2 3}$ \\
Sugarcane & $(8.18)$ & $(11.41)$ & $\mathbf{( 5 . 5 3 )}$ \\
\hline & $\mathbf{1 . 9 1}$ & $\mathbf{4 . 7 0}$ & $\mathbf{2 . 7 9}$ \\
\hline Potato & $(\mathbf{1 3 . 3 7}$ & $\mathbf{( 1 1 . 9 1 )}$ & $\mathbf{( 1 8 . 7 2 )}$ \\
\hline
\end{tabular}

Figures in parentheses shows coefficient of variation $(\mathrm{CV})$

The coefficients for estimating CGR of production and yield under oilseeds came out to be insignificant so the negative growth rate of production ( -2.23 per cent) and yield $(-2.22$ per cent) under oilseeds was interpreted during 1991-09.

Sugarcane and Potato are main cash crops of Uttar Pradesh. Sugarcane and potato together constituted about 12 per cent share in gross cropped area in TE 2009. Between 1991 and 2009, these crops showed impressive performance in their production and in fact, surpassed cereals, pulses and oilseeds in area and production and yield growth. Total area under sugarcane increased from about 17 lakh hectare in TE 1995 to 21.78 lakh hectare in TE 2009 exhibiting a growth rate of 1.10 per cent per annum. Increase in area under sugarcane might be because of growing demand, increasing commercialisation, better infrastructure and improved marketing facilities.

In the same period, the share of potato in gross cropped area increased from 1.66 per cent to 1.88 per cent. With the significant growth in the area under potato, total area under potato increased from 3.88 lakh tonnes to 5.32 lakh tonnes at a growth rate of about 2.09 per cent per annum during 1991 to 2009. The production of potato increased from 64.18 lakh tonnes in 1995 to 101.02 lakh tonnes in 2009. The growth rate in production and productivity of potato was 4.70 per cent and 2.79 per cent during 1991-2009, respectively.

Thus, it can be summarized that cereals still occupy major share in cropping pattern and instability in yield of pulses and oilseeds was higher. In the recent period, increasing shift towards crops like sugarcane and potato was observed which resulted in their better production performance and yield as compared to staple crops such as cereals and pulses. Difference in cropping pattern and production performance of agricultural crops emphasize location specific technological and policy interventions for sustainable production. Efforts should be made towards improving pulses production which showed high instability and poor performance in the state.

\section{References}

Ahluwalia, M.S. 1978. "Rural Poverty and Agricultural Performance in India", Journal of Development Studies, 14(2): 298-323. 
Bera, B. K., Chakraborty, A.J, Nandi, A. K. and A. Sarkar (2011),"Growth and instability of food grains production of India and West Bengal", Journal of Crop and Weed, 7: 1, 94- 100.

Fahimuddin (2010), "Diversification of agriculture in Uttar Pradesh: need for policy reorientation", Journal of Rural Development (Hyderabad), 29: 2, 141156.

Gajbhiye, Sonal, Wankhade, R. N. and Kakde, S. J. (2010), "Growth and instability of chickpea production in Vidarbha region of Maharashtra", International Journal of Commerce and Business Management; 3: 2, 172174.

Gawade, N. A., Talathi, J.M and Kamble, S.H. (2007), "Instability in agricultural production", International Journal of Agricultural Sciences, 3:2, 306-312.

Hussain, I. and Hanjra, M.A. 2003. "Does Irrigation Water Matter for Rural Poverty Alleviation? Evidence from South and South-East Asia", Water Policy, 5(5-6): 429-442.Kachroo, Jyoti, Dileep and Sharma, Arti (2010), "Growth and instability of major oilseeds of India based on logistic and
Coppock's model", Agricultural Situation in India, 66: 10, 589-600.

Kumar, Sanjeev and Taneja, N. K. (2008), "Agricultural growth and performance of Uttar Pradesh: A total factor productivity analysis", Agricultural Situation in India, 65: 7, 463- 469.

Pochanna, K. (2004), “A study on growth and instability of crop production in Andhra Pradesh: A district level analysis from 1971-2001", Anvesak 34: 1, 9-36.

Rai, J., Yadav, A.K., and R. K. Rai (2007), "Role of castor seed production in farmers' economy in district Kanpur, Uttar Pradesh”, Agricultural Economics Research Review (Conference Issue), Vol 20, pp.585.

Saleth, M.R., Samad, M., Molden, D. and Hussain, I. 2003. "Water, Poverty and Gender: A Review of Issues and Policies", Water Policy, 5(5-6): 38598.

Verma, M.R., Datta, K. K., Mandal, Subhasis and Tripathi, A. K. (2007), "Diversification of food production and consumption patterns in India", Journal of Agricultural \& Food Information, 8: 3, 87-100. 22.

\section{How to cite this article:}

Rooba Hasan and Diwan Nayeer Khan. 2018. Temporal Analysis of Agricultural Production and its Performance in Uttar Pradesh, India. Int.J.Curr.Microbiol.App.Sci. 7(06): 3503-3508. doi: https://doi.org/10.20546/ijcmas.2018.706.410 